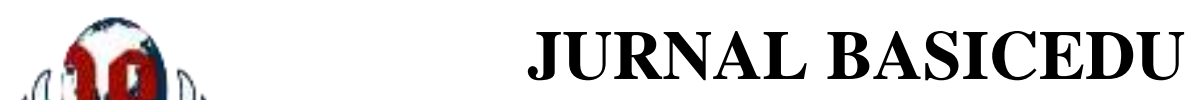

Volume 5 Nomor 5 Tahun 2021 Halaman 3799 - 3813

Research \& Learning in Elementary Education

https://jbasic.org/index.php/basicedu

PATLAMAN

\title{
Pengembangan Multimedia Interaktif Berbasis Powtoon pada Pembelajaran Tematik di Sekolah Dasar
}

\author{
Rama Donna $^{1 凶}$, Asep Sukenda Egok ${ }^{2}$, Riduan Febriandi ${ }^{3}$ \\ STKIP-PGRI Lubuklinggau, Indonesia ${ }^{1,2,3}$ \\ E-mail: ramadonna123@gmail.com ${ }^{1}, \underline{\text { asep.egok91@gmail.com }}^{2}, \underline{\text { riduanfebriandi9@gmail.com }}^{3}$
}

\begin{abstract}
Abstrak
Penelitian ini bertujuan untuk mengembangkan multimedia interaktif berbasis Powtoon pada pembelajaran Tematik kelas V SD Negeri 20 Rejang Lebong serta untuk menghasilkan multimedia interaktif yang valid, praktis dan memiliki efek potensial. Jenis penelitian yaitu Research and Development dengan model pengembangan 4-D (Four-D). Subjek penelitian ini adalah siswa-siswi kelas V SD Negeri 20 Rejang Lebong. Teknik pengumpulan data yang digunakan adalah wawancara, observasi, angket dan tes. Berdasarkan hasil analisis penilaian oleh ketiga ahli yaitu: ahli bahasa, ahli materi, dan ahli media menunjukkan bahwa multimedia interaktif berbasis PowToon memenuhi kriteria valid dengan rata-rata skor 0,78 . Sedangkan dari hasil analisis penilaian lembar kepraktisan guru dan siswa diperoleh bahwa multimedia interaktif berbasis PowToon memenuhi kriteria praktis dengan rata-rata skor 99\%. Pada uji lapangan diperoleh $\mathrm{N}$-gain $(\mathrm{g})$ sebesar 0,797 dengan klasifikasi tinggi, yang artinya multimedia interaktif berbasis PowToon memiliki efek potensial yang tinggi. Berdasarkan hasil penelitian dapat disimpulkan bahwa multimedia interaktif berbasis PowToon terbukti valid, praktis dan memiliki efek potensial pada pembelajaran tematik kelas V Sekolah Dasar.
\end{abstract}

Kata Kunci: Multimedia Interaktif, PowToon, Tematik.

\begin{abstract}
This study aims to develop interactive multimedia based on PowToon for fifth grade students of thematic learning at SD Negeri 20 Rejang Lebong and produce interactive multimedia that are valid, practical and have potential effects. The type of the research is Research and Development with a 4-D (Four-D) development model. The subjects of this study were the fifth grade students of SD Negeri 20 Rejang Lebong. Data collection techniques in the study were interviews, observations, questionnaires and tests. Based on the results of the analysis based on the experts, namely: linguists, material experts, and media experts determine interactive multimedia based on PowToon meet the criteria with an average score of 0.78. Based on the analysis of teacher and student obtained from interactive multimedia based on PowToon meet the requirements with an average score of 99\%. In the field test results received $N$-gain $(g)$ of 0.797 with a high classification, which means that PowToon-based interactive multimedia has a high potential effect. Based on the results of the study, it can be concluded that PowToon-based interactive multimedia is proven to be valid, practical and has a potential effect on thematic learning of fifth grade elementary school.
\end{abstract}

Keywords: Interactive Multimedia, PowToon, Thematic.

Copyright (c) 2021 Rama Donna, Asep Sukenda Egok, Riduan Febriandi

Corresponding author :

Email : ramadonna123@gmail.com

DOI $\quad$ : https://doi.org/10.31004/basicedu.v5i5.1382

ISSN 2580-3735 (Media Cetak)

ISSN 2580-1147 (Media Online)

Jurnal Basicedu Vol 5 No 5 Tahun 2021

p-ISSN 2580-3735 e-ISSN 2580-1147 
3800 Pengembangan Multimedia Interaktif Berbasis Powtoon pada Pembelajaran Tematik di Sekolah Dasar-Rama Donna, Asep Sukenda Egok, Riduan Febriandi

DOI: https://doi.org/10.31004/basicedu.v5i5.1382

\section{PENDAHULUAN}

Pendidikan adalah usaha sadar dan terencana untuk mewujudkan suasana belajar dan proses pembelajaran agar peserta didik secara aktif mengembangkan potensi dirinya untuk memiliki kekuatan spiritual keagamaan, pengendalian diri, kepribadian, kecerdasan, akhlak mulia, serta keterampilan yang diperlukan dirinya, masyarakat, bangsa dan Negara (Undang-Undang Nomor 20 Tahun 2003 Tentang Sistem Pendidikan Nasional., n.d.). Pada dasarnya melalui pendidikan, setiap manusia didorong untuk dapat mengembangkan kualitas dirinya, apalagi di zaman modern seperti sekarang dimana teknologi berkembang begitu pesatnya.

Teknologi saat ini mengalami kemajuan yang luar biasa. Di setiap penjuru dunia, memanfaatkan teknologi dalam berbagai bidang, sehingga membantu dalam menyelesaikan berbagai macam permasalahan. Berkaitan dengan pesatnya perkembangan teknologi, membuat setiap orang dapat mencari apapun di internet termasuk materi pelajaran, sehingga peserta didik dapat memanfaatkan hal tersebut untuk mencari hal-hal yang belum ia ketahui. Akan tetapi, hal ini juga berdampak bagi guru. Seperti yang diungkapkan oleh Awalia et al., (2019:49) bahwa perkembangan teknologi yang semakin cepat memunculkan pertanyaan terhadap tugas guru, masihkah diperlukan mengajar secara konvensional. Seperti mencatat materi dan menyuruh siswa menyalinnya. Untuk itu, guru harus mengembangkan potensinya sesuai dengan perkembangan teknologi, sehingga tugas guru dapat mengimbangi perkembangan teknologi.

Kemajuan teknologi dapat mempermudah meningkatkan kualitas pembelajaran, salah satunya terdapat pada media pembelajaran (Musofa \& Janattaka, 2019:147). Penggunaan media pembelajaran juga dapat membantu dalam memberikan pembelajaran di Sekolah Dasar, yang sistem pembelajarannya menggunakan pembelajaran Tematik.

Pembelajaran Tematik merupakan pembelajaran yang memadukan berbagai mata pelajaran dengan lingkungan sehari-hari siswa sebagai sumber belajarnya. Dalam penerapannya, Ponza et al., (2018:10) mengungkapkan bahwa pembelajaran Tematik di Sekolah Dasar ada beberapa yang bersifat abstrak, sehingga kadang siswa bingung untuk memahaminya. Konsep Tematik selalu berkaitan dengan lingkungan sehari-hari. Oleh karena itu, banyak fenomena yang bisa dijadikan sebagai sumber dalam belajar Tematik di lingkungan.

Berdasarkan hasil observasi yang dilakukan peneliti di SD Negeri 20 Rejang Lebong, pada hari Rabu tanggal 18 November 2020, bahwa pada saat guru mengajar masih menggunakan metode ceramah. Penggunaan media pembelajaran dalam proses belajar-mengajar masih belum terlihat. Sumber belajarnya masih berupa buku tema siswa dan buku tema untuk guru. Siswa masih pasif dalam belajar. Rata-rata siswa kurang antusias dalam belajar, karena kurangnya penggunaan media pembelajaran. Sekolah juga masih terbatas ketersediaan media-media yang mendukung pembelajaran. Media yang ada yaitu berupa media gambar, alat peraga sederhana dan LCD proyektor. Terlihat bahwa sekolah sudah memadai untuk menggunakan LCD proyektor, maka dlam penerapan media video atau multimedia sudah bisa dilakukan. Pembelajaran Tematik masih bersifat abstrak sehingga guru dalam memberikan pembelajaran mengalami kesulitan. Jadi, dapat dikatakan bahwa pembelajarannya masih konvensional tanpa media yang menarik. Padahal suatu pembelajaran harus dapat menstimulus siswa agar tertarik untuk belajar, sehingga tujuan pembelajaran dapat tercapai. Sejalan dengan yang disampaikan oleh Arsyad (2019:2) bahwa media merupakan bagian yang tidak terpisahkan dari proses pembelajaran, karena dengan media tujuan pendidikan dapat tercapai.

Salah satu media yang dapat membuat siswa tertarik dalam belajar yaitu multimedia interaktif berbasis PowToon. Media pembelajaran ini akan berbentuk video yang di dalamnya memuat gambar, teks, suara, animasi yang menarik. Guru dapat menggunakan beberapa aplikasi yang dapat disajikan dalam bentuk video, diantaranya yaitu Videoscribe, PowToon, Animeker, dan sebagainya (Awalia et al., 2019:51). 
3801 Pengembangan Multimedia Interaktif Berbasis Powtoon pada Pembelajaran Tematik di Sekolah Dasar-Rama Donna, Asep Sukenda Egok, Riduan Febriandi

DOI: https://doi.org/10.31004/basicedu.v5i5.1382

PowToon merupakan aplikasi berbasis web online yang disediakan bagi pengguna untuk membuat presentasi animasi dengan fitur yang sangat menarik. Diantaranya animasi tangan, animasi kartun, dan efek transisi yang lebih hidup serta pengaturan timeline yang mudah (Anjarsari et al., 2020:42). Dapat dikatakan bahwa, PowToon dapat membuat sebuah animasi yang berisi materi-materi dengan kemasan yang menarik.

Multimedia interaktif mempunyai segudang manfaat. Seperti yang diungkapkan oleh (Febriandi, 2020:121) bahwa multimedia mempunyai beragam manfaat seperti dapat digunakan pada media pembelajaran, game, film, dunia medis, militer, bisnis, desain, promosi arsitektur, bidang olahraga, hobi, dan sebagainya. Diungkapkan pula oleh (Suryani et al., 2018:201) bahwa media interaktif memungkinkan siswa berinteraksi dengan mempraktikkan keterampilan dan menerima umpan balik dari materi yang disampaikan.

Penggunaan multimedia interaktif berbasis PowToon ini didasarkan pada penelitian sebelumnya yang dilakukan oleh (Ponza et al., 2018:17) yang menyatakan bahwa video pembelajaran yang dibuat dengan PowToon terbukti efektif secara signifikan dapat meningkatkan hasil belajar bahasa Tematik. Perbedaan dari penelitian ini dengan penelitian sebelumnya, yaitu berbagai animasi digunakan untuk dijadikan suatu ilustrasi yang berkaitan dengan kehidupan sehari-hari, menggunakan rekaman suara sebagai pendukung untuk memperjelas materi yang disajikan, dan bersifat interaktif yaitu adanya interaksi antara siswa dan media serta pembelajaran yang disajikan berupa pembelajaran Tematik. Tidak hanya itu, multimedia ini akan dilengkapi permainan interaktif.

Berdasarkan permasalahan tersebut, maka peneliti tertarik melakukan penelitian berjudul "Pengembangan Multimedia Interaktif Berbasis PowToon Pada Pembelajaran Tematik Kelas V SD Negeri 20 Rejang Lebong".

\section{METODE PENELITIAN}

Metode penelitian yang digunakan oleh peneliti yaitu Research and Development ( $\mathrm{R} \& \mathrm{D})$. Menurut Sugiyono (2016:297), metode penelitian dan pengembangan (research and development) adalah metode penelitian yang digunakan untuk menghasilkan produk tertentu dan menguji keefektifan produk tersebut. Desain dan pengembangan multimedia interaktif berbasis PowToon menggunakan model pengembangan Four-D (4D) yang mempunyai empat tahapan, yaitu Define (Pembatasan), Design (Perancangan), Develop (Pengembangan), Disseminate (Penyebaran). Model 4D dapat diadaptasi menjadi 4P, yaitu Pendefinisian, Perancangan, Pengembangan dan Penyebaran (Trianto, 2010:93).

Melalui penelitian dan pengembangan ini, peneliti akan mengembangkan produk yang valid, praktis dan memiliki efek potensial. Kevalidan produk akan diukur melalui penyebaran angket untuk para ahli yaitu ahli bahasa, ahli materi dan ahli media. Untuk mengetahui tingkat kepraktisan akan diberikan angket untuk siswa melalui uji coba kelompok kecil dan uji lapangan serta angket juga diberikan kepada guru. Dan untuk mengetahui ada tidaknya efek potensial multimedia interaktif, peneliti akan memberikan tes berupa pretest dan posttest.

\section{Teknik Pengumpulan Data}

Wawancara

Hamzah (2019:125), menjelaskan bahwa wawancara dilakukan dengan cara mengajukan pertanyaanpertanyaan secara langsung kepada sasaran penelitian. Namun, wawancara juga dapat dilakukan dengan memanfaatkan media komunikasi seperti email, telepon, skype dan lain-lain. Menurut Sugiyono (2016:138), Peneliti dapat melakukan wawancara terstruktur dan tidak terstruktur. Wawancara terstruktur digunakan sebagai teknik pengumpulan data apabila peneliti telah mengetahui dengan pasti tentang informasi apa yang akan didapatkan. Wawancara dilakukan dengan memberikan 20 pertanyaan secara langsung kepada guru kelas V SD Negeri 20 Rejang Lebong. 
3802 Pengembangan Multimedia Interaktif Berbasis Powtoon pada Pembelajaran Tematik di Sekolah Dasar - Rama Donna, Asep Sukenda Egok, Riduan Febriandi

DOI: https://doi.org/10.31004/basicedu.v5i5.1382

\section{Observasi}

Observasi merupakan teknik pengumpulan data yang mempunyai ciri yang spesifik dibandingkan dengan teknik yang lain, seperti wawancara dan angket. Apabila wawancara dan angket selalu berkomunikasi dengan orang, maka observasi tidak terbatas pada orang (Sugiyono, 2017:145). Selain itu, Hamzah (2019:123) mengatakan bahwa observasi merupakan teknik pengumpulan data dengan mengamati secara langsung suatu keadaan atau situasi dan sebuah subjek penelitian. Jadi, dapat dikatakan tujuan observasi ini dilakukan yaitu mengetahui keadaan atau situasi ketika guru melakukan pembelajaran di kelas. Selain itu saat guru memberikan pembelajaran di kelas, juga diamati kelengkapan peralatan sebelum memulai pembelajaran seperti RPP dan media pembelajaran.

Angket

Sugiyono (2016:142), mengatakan bahwa angket atau kuesioner ialah suatu teknik pengumpulan data yang efisien bila peneliti tahu dengan pasti variabel yang akan diukur dan tahu apa yang bisa diharapkan dari responden. Selain itu, angket (kuesioner) juga cocok digunakan bila jumlah responden cukup besar dan tersebar diwilayah luas. Jadi, dapat dikatakan bahwa penggunaan angket dapat membantu dalam proses pengumpulan data, dengan mengisi pertanyaan-pertanyaan yang akan diajukan kepada responden.

Pada penelitian ini akan ada dua angket yaitu angket kevalidan multimedia dan angket respon guru dan siswa. Instrumen penelitian menggunakan uji angket tertutup dan dibuat dalam bentuk ceklist. Pada pengisian angket diberikan tanda centang $(\sqrt{ })$ pada pilihan jawaban yang sesuai dengan pendapat atas pernyataan yang diajukan. Angket penilaian multimedia interaktif berbasis PowToon ini diberikan kepada dosen sebagai ahli bahasa, ahli materi, dan ahli media. Angket penilaian ini bermanfaat untuk mengetahui kualitas kevalidan multimedia interaktif berbasis PowToon yang dikembangkan.

Angket respon guru berupa uji angket tertutup berisi beberapa pernyataan menggunakan checklist $(\sqrt{ })$ yang dihitung dengan dengan skor yang digunakan terdiri dari 4, 3, 2, 1 yang masing-masing menunjukkan penilaian Sangat Baik (SB), Baik (B), Kurang Baik (KB), dan Sangat Tidak Baik (STB). Sedangkan angket respon siswa akan diberikan kepada siswa pada akhir pembelajaran. Instrumen ini bertujuan untuk mengetahui kualitas kepraktisan berdasarkan respon dan tanggapan siswa. Pada pengisian angket menggunakan checklist $(\sqrt{ })$ yang dihitung dengan menggunakan skala Guttman dengan skor yang digunakan terdiri dari 1 dan 0 yang masing-masing menunjukkan penilaian "Ya" dan "Tidak".

Tes

Mahmud (2011:185), mengatakan bahwa tes merupakan rangkaian pertanyaan yang dapat digunakan untuk mengukur keterampilan, tingkat kognitif, kemampuan dan bakat yang dimiliki oleh individu maupun kelompok. Selain itu, Hamzah (2019:127) mengatakan bahwa instrumen tes dapat berupa pertanyaan, lembar kerja atau sejenisnya yang dapat digunakan untuk mengukur pengetahuan, keterampilan dan bakat dari subjek penelitian serta lembar instrumen tes berisi soal-soal tes yang terdiri atas butir-butir soal. Jadi, dalam penelitian ini akan melakukan tes berupa pretest dan posttest terhadap siswa-siswi SD Negeri 20 Rejang Lebong. Tes dilakukan untuk melihat efek potensial dari multimedia interaktif berbasis PowToon. Tes berupa soal pilihan ganda berjumlah 15 soal.

\section{Teknik Analisis Data}

Analisis Kevalidan

Kevalidan multimedia interaktif berbasis PowToon didapatkan dari angket dosen ahli bahasa, ahli materi dan ahli media. Hasil validasi lembar penilaian kevalidan multimedia interaktif berbasis PowToon dianalisis dengan langkah-langkah sebagai berikut:

a. Tabulasi Data, pedoman pemberian skor multimedia interaktif berbasis PowToon. 
3803 Pengembangan Multimedia Interaktif Berbasis Powtoon pada Pembelajaran Tematik di Sekolah Dasar - Rama Donna, Asep Sukenda Egok, Riduan Febriandi

DOI: https://doi.org/10.31004/basicedu.v5i5.1382

Tabel 1 Pedoman Pemberian Skor Lembar Penilaian Kevalidan Multimedia

\begin{tabular}{cc}
\hline Skor & Kriteria \\
\hline 4 & Sangat Baik \\
\hline 3 & Baik \\
\hline 2 & Kurang Baik \\
\hline 1 & Sangat Kurang Baik \\
\hline \multicolumn{2}{l}{ (Modifikasi Sugiyono, 2016:93) }
\end{tabular}

b. Menghitung nilai validitas menggunakan rumus Aikens's $V$ sebagai berikut:

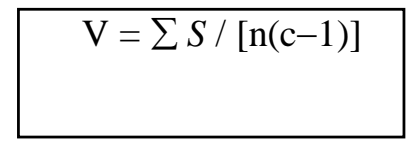

(Azwar (dalam (Lestari et al., 2021:398)

\section{Keterangan:}

$\mathrm{S} \quad=\mathrm{r}-\mathrm{lo}$

lo $\quad=$ Angka penilaian validitas terendah (dalam hal ini $=1)$

$\mathrm{c} \quad=$ Angka penilaian validitas tertinggi (dalam hal ini $=4$ )

$\mathrm{r} \quad=$ Angka yang diberikan oleh seorang penilai

c. Mengubah skor rata-rata seluruh aspek menjadi nilai kualitatif sesuai dengan kriteria penilaian.

Tabel 2 Interpretasi Validitas Aiken's $V$

\begin{tabular}{cc}
\hline Koefisien Korelasi & Interpretasi Validitas \\
\hline$>0,80$ & Tinggi \\
\hline $0,60 \leq V<0,80$ & Cukup Tinggi \\
\hline $0,40 \leq V<0,60$ & Cukup \\
\hline $0 \leq V<0,40$ & Buruk \\
\hline \multicolumn{2}{c}{ (Febriandi et al., 2019:152) }
\end{tabular}

Analisis Kepraktisan

Data lembar penilaian kepraktisan multimedia interaktif berbasis PowToon dianalisis dengan langkahlangkah sebagai berikut:

a. Tabulasi Data, pedoman pemberian skor multimedia interaktif pada angket respon guru dan siswa.

Tabel 3 Pedoman Pemberian Skor Pada Angket Respon Guru

\begin{tabular}{cc}
\hline Skor & Kriteria \\
\hline 4 & Sangat Baik \\
\hline 3 & Baik \\
\hline 2 & Kurang Baik \\
\hline 1 & Sangat Kurang Baik \\
\hline \multicolumn{2}{c}{ (Modifikasi Sugiyono, 2016:93) }
\end{tabular}

Tabel 4 Pedoman Pemberian Skor Pada Angket Respon Siswa

\begin{tabular}{cc} 
Skor & Kriteria \\
\hline 1 & Ya \\
\hline 0 & Tidak \\
\hline \multicolumn{2}{c}{ (Modifikasi Sugiyono, $2017: 96)$}
\end{tabular}


3804 Pengembangan Multimedia Interaktif Berbasis Powtoon pada Pembelajaran Tematik di Sekolah Dasar - Rama Donna, Asep Sukenda Egok, Riduan Febriandi

DOI: https://doi.org/10.31004/basicedu.v5i5.1382

b. Pemberian nilai kepraktisan menggunakan rumus sebagai berikut:

$$
\text { Tingkat Kepraktisan }=\frac{\text { Jawaban Skor yang diperoteh }}{\text { Jumlah Skor Total }} \times 100 \%
$$

(Hidayat \& Irawan, 2017:56)

c. Mengubah skor rata-rata seluruh aspek menjadi nilai kualitatif sesuai dengan kriteria penilaian.

Tabel 5 Pedoman Pengubahan Tingkat Kepraktisan Menjadi Data Kualitatif

\begin{tabular}{cc}
\hline Interval Rata-rata Skor & Klasifikasi \\
\hline $81 \%-100 \%$ & Sangat Praktis \\
\hline $61 \%-80 \%$ & Praktis \\
\hline $41 \%-60 \%$ & Cukup Praktis \\
\hline $21 \%-40 \%$ & Kurang Praktis \\
\hline $0 \%-20 \%$ & Tidak Praktis \\
\hline Riduan (dalam Hidayat \& Irawan, 2017:56)
\end{tabular}

Analisis Efek Potensial

Tes yang diberikan pada akhir penelitian ini bertujuan untuk melihat efek potensial multimedia interaktif berbasis PowToon. Data soal tes dianalisis dengan langkah-langkah sebagai berikut:

a. Siswa akan menjalankan tes berupa pretest dan posttest.

b. Memberikan soal tes berupa 15 soal pilihan ganda dan menghitung skor dari jawaban siswa. Skor benar yaitu 1 dengan skor maksimal 15 .

c. Menentukan nilai akhir dengan rumus, sebagai berikut.

$$
\text { Nilai Akhir }=\frac{\text { Skor yang diperoleh }}{\text { Skor Maksimal }} \times 100
$$

(Modifikasi Navirida, 2017:5)

d. Menghitung rata-rata hasil pretest dan posttest dengan rumus sebagai berikut.

$$
\bar{X}=\frac{\sum x}{n}
$$

(Modifikasi Istiqlal, 2017:49)

e. Dari hasil rata-rata pretest dan posttest akan dihitung hasil tes dengan rumus N-gain (g).

$$
N-\operatorname{gain}(g)=\frac{\text { Spost }- \text { Spre }}{\text { Smaks }- \text { Spre }}
$$

(Siregar et al., 2017:47)

Keterangan :

$\mathrm{N}$-gain $(\mathrm{g})=$ Normalized

Spost $\quad=$ Skor Post Test (Dalam Rata-rata)

Smaks $=$ Skor maksimum

Spre $\quad=\quad$ Skor Pre Test (Dalam Rata-rata)

f. Setelah itu, hasil N-gain akan diklasifikasikan menggunakan pada tabel 6 di bawah ini.

Tabel 6 Klasifikasi N-gain(g)

\begin{tabular}{cc}
\hline Besarnya N-gain $(\mathrm{g})$ & Klasifikasi \\
\hline $\mathrm{g}>0,7$ & Tinggi \\
\hline $0,3 \leq \mathrm{g} \leq 0,7$ & Sedang \\
\hline $\mathrm{g}<0,3$ & Rendah \\
\hline (Hake (Siregar et al., 2017:48)
\end{tabular}


3805 Pengembangan Multimedia Interaktif Berbasis Powtoon pada Pembelajaran Tematik di Sekolah Dasar-Rama Donna, Asep Sukenda Egok, Riduan Febriandi

DOI: https://doi.org/10.31004/basicedu.v5i5.1382

\section{HASIL DAN PEMBAHASAN}

Pengembangan multimedia interaktif berbasis PowToon menggunakan model pengembangan Four-D (4D) yang mempunyai empat tahapan, yaitu Define (Pendefinisian), Design (Perancangan), Develop (Pengembangan), Disseminate (Penyebaran).

Tahap Pendefinisian (Define)

Tahap pendefinisian (Define) ini dilakukan dengan pertama analisis awal kemudian analisis siswa dengan cara yaitu menganalisis kebutuhan dari hasil observasi di SD Negeri 20 Rejang Lebong. Ada beberapa komponen yang dianalisis, dimulai sebelum guru memberikan pembelajaran, saat pembelajaran berlangsung dan keaktifan siswa saat belajar.

Tabel 7 Analisis Awal Kebutuhan Multimedia Interaktif Berbasis PowToon

Keadaan Sekarang Keadaan yang Diharapkan

1) Belum adanya media pembelajaran berbasis Adanya media pembelajaran berbasis multimedia multimedia interaktif di SD Negeri 20 interaktif di SD Negeri 20 Rejang Lebong.

Rejang Lebong.

2) Hanya menggunakan metode ceramah ketika Diharapkan pembelajaran akan lebih bervariasi, proses pembelajaran berlangsung. karena pada multimedia tidak hanya materi pembelajaran saja tetapi ada video pembelajaran dan permainan interaktif.

3) Guru masih kesulitan dalam memberikan Diharapkan dengan multimedia akan memudahkan pembelajaran tematik yang bersifat abstrak. guru dalam memberikan pembelajaran tematik dengan lebih nyata dan sesuai dengan pengalaman sehari-hari siswa.

Tabel 8 Analisis Keadaan Siswa Ketika Belajar

Keadaan Sekarang Keadaan yang Diharapkan

1) Belum banyak berinteraksi antara guru Adanya interaksi antara guru dengan siswa ketika dengan siswa ketika proses belajar proses belajar berlangsung. berlangsung.

2) Siswa masih bingung ketika proses Diharapkan dengan multimedia siswa belajar pembelajaran di kelas. menyenangkan dan mampu menjawab setiap pertanyaan.

3) Siswa pasif dalam belajar dan kurang Siswa lebih aktif karena dengan multimedia siswa berpartisipasi ketika belajar. tidak hanya mengamati tetapi juga ada permainan interaktif yang membuat siswa lebih interaktif ketika belajar. Sehingga siswa lebih berpartisipasi ketika belajar.

Ketiga, analisis tugas dilakukan dengan tujuan untuk menjabarkan isi materi yang diajarkan dalam bentuk garis-garis besar. Penyusunan multimedia interaktif berpedoman pada kompetensi dasar yang sesuai dengan Tema 9 Subtema 3. Keempat, analisis konsep bertujuan untuk mengidentifikasi konsep-konsep pokok yang akan diajarkan dan merinci secara sistematis dengan cara mengelompokkan materi Tema 9 Subtema 3 yaitu pada mata pelajaran Bahasa Indonesia akan membahas tentang iklan, PPKn akan memuat materi persatuan dan kesatuan, IPS akan terdapat materi kegiatan ekonomi dan menghargai keanekaragaman mata pencaharian masyarakat, IPA akan membahas zat tunggal dan campuran dan SBdP akan membahas mengenai seni rupa daerah (batik). Kelima, perumusan tujuan pembelajaran. Hasil dari analisis tugas dan analisis konsep digunakan sebagai tolak ukur untuk merumuskan indikator pencapaian hasil belajar dan tujuan pembelajaran, kompetensi dasar (KD). 

Dasar-Rama Donna, Asep Sukenda Egok, Riduan Febriandi

DOI: https://doi.org/10.31004/basicedu.v5i5.1382

Tahap Perancangan (Design)

Tahap perancangan (Design) ini memiliki tujuan menghasilkan rancangan awal multimedia interaktif yaitu menyiapkan prototype perangkat pembelajaran, dengan langkah yaitu pertama penyusunan tes acuan patokan. Penyusunan tes sesuai dari tujuan pembelajaran menjadi tolak ukur kemampuan siswa berupa 15 soal pilihan ganda yang berkaitan dengan Tema 9 "Benda-benda di Sekitar Kita" Subtema 3 "Manusia dan Benda di Lingkungannya". Kedua, pemilihan media. Pemilihan media dalam penelitian ini berupa multimedia interaktif berbasis PowToon. Multimedia akan dibuat di web online PowToon dan akan dikombinasikan dengan Linktree, Educandy, Kahoot! serta untuk media akhirnya akan berupa Kartu Sahabat MuToon yang di dalamnya sudah tersedia QR Code untuk mengoperasikan multimedia interaktif berbasis PowToon. Ketiga, pemilihan format. Pemilihan format kriteria multimedia interaktif berbasis PowToon dan materi yang termuat dalam multimedia interaktif sesuai dengan Tema 9 "Benda-benda di Sekitar Kita" Subtema 3 "Manusia dan Benda di Lingkungannya". Keempat, desain awal multimedia. Penyusunan draf awal multimedia akan menghasilkan draf yang di dalamnya sekurang-kurangnya mencakup judul yang menggambarkan materi yang akan dituangkan di dalam multimedia interaktif, Kartu Sahabat MuToon (Multimedia Interaktif PowToon) beserta QR Code dan petunjuk penggunaan dan video pembelajaran, permainan interaktif, RPP, Silabus dan petunjuk penggunaan.

Tahap Pengembangan (Develop)

Pada tahap pengembangan (Develop) dilakukan dengan tujuan untuk menghasilkan multimedia interaktif berbasis PowToon dalam pembelajaran Tematik yang sudah divalidasi berdasarkan masukan dan saran dari ahli serta telah diuji coba ke siswa dan guru. Desain awal multimedia interaktif berbasis PowToon yang telah divalidasi oleh ahli bahasa, ahli materi, dan ahli media serta telah diuji coba pada kelompok kecil dan uji lapangan menghasilkan produk final dari multimedia interaktif berbasis PowToon.

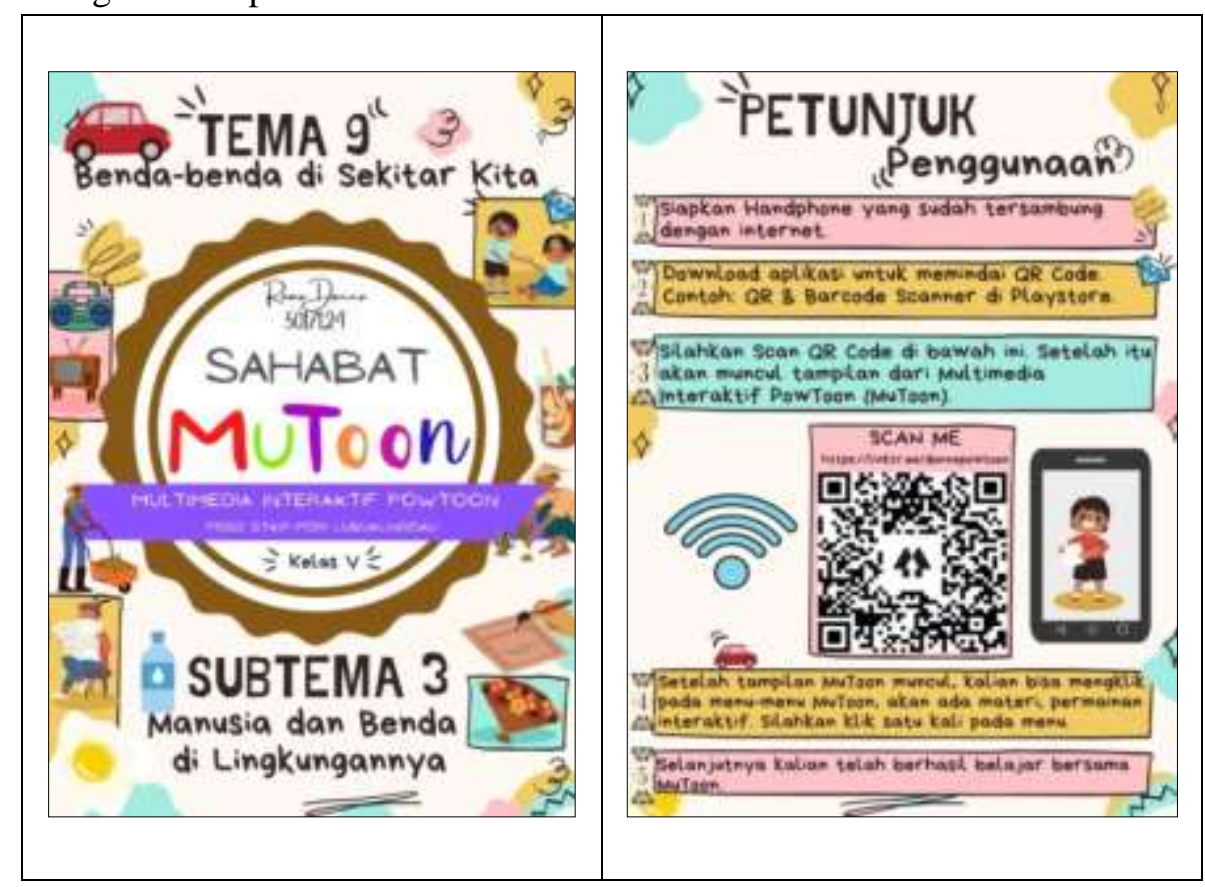

Gambar 1 Kartu Sahabat MuToon (Multimedia Interaktif PowToon) 
3807 Pengembangan Multimedia Interaktif Berbasis Powtoon pada Pembelajaran Tematik di Sekolah Dasar-Rama Donna, Asep Sukenda Egok, Riduan Febriandi

DOI: https://doi.org/10.31004/basicedu.v5i5.1382
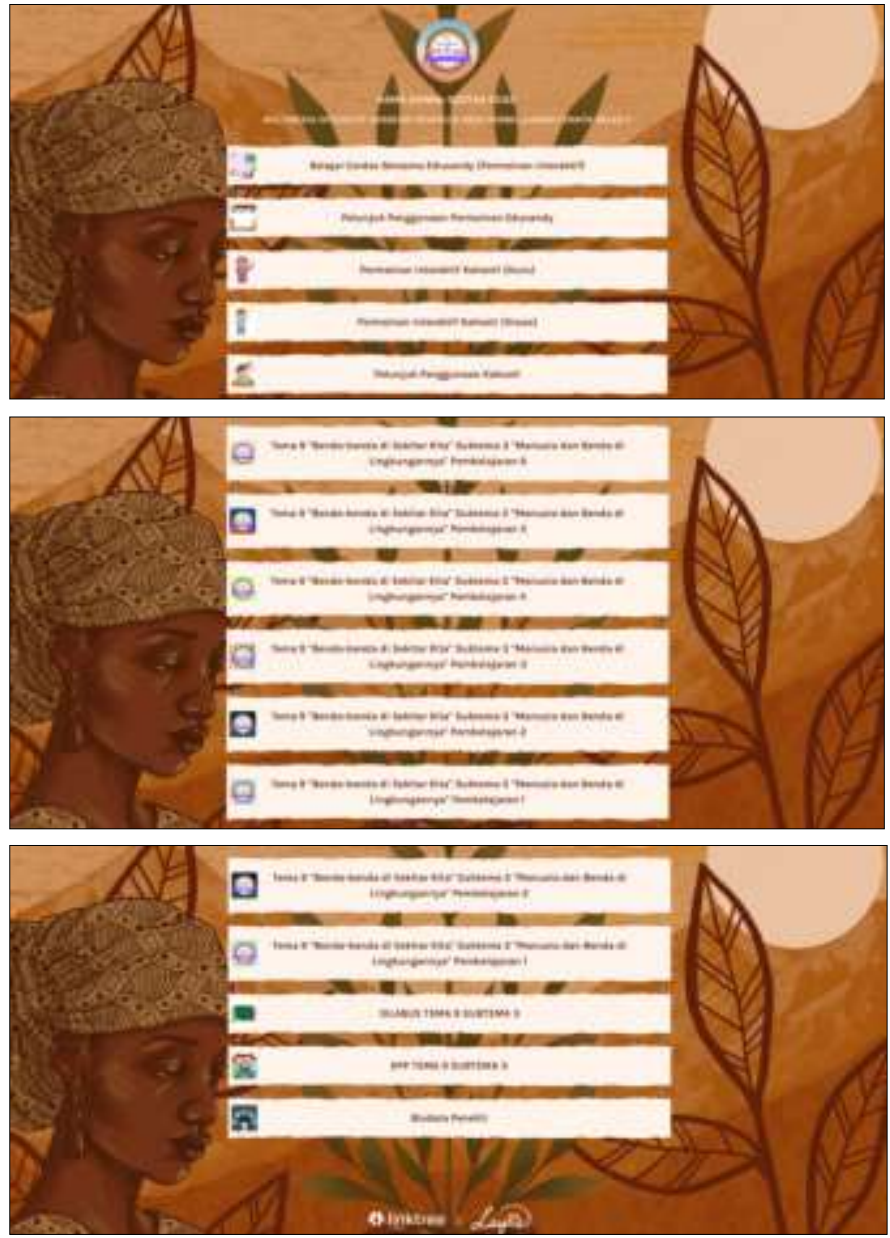

Gambar 2 Tampilan Multimedia Interaktif

Berbasis PowToon Setelah discan QR Codenya

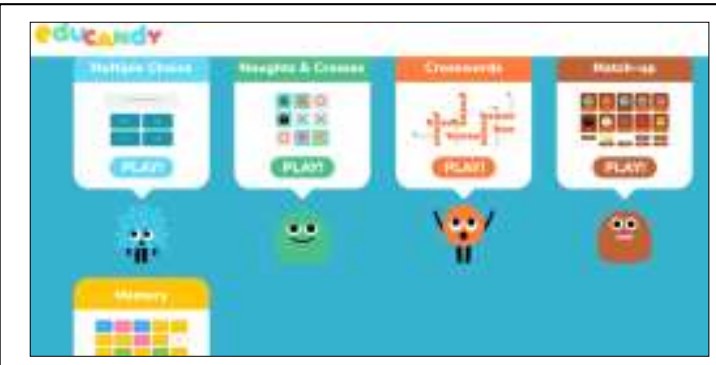

Gambar 3 Tampilan Permainan Educandy
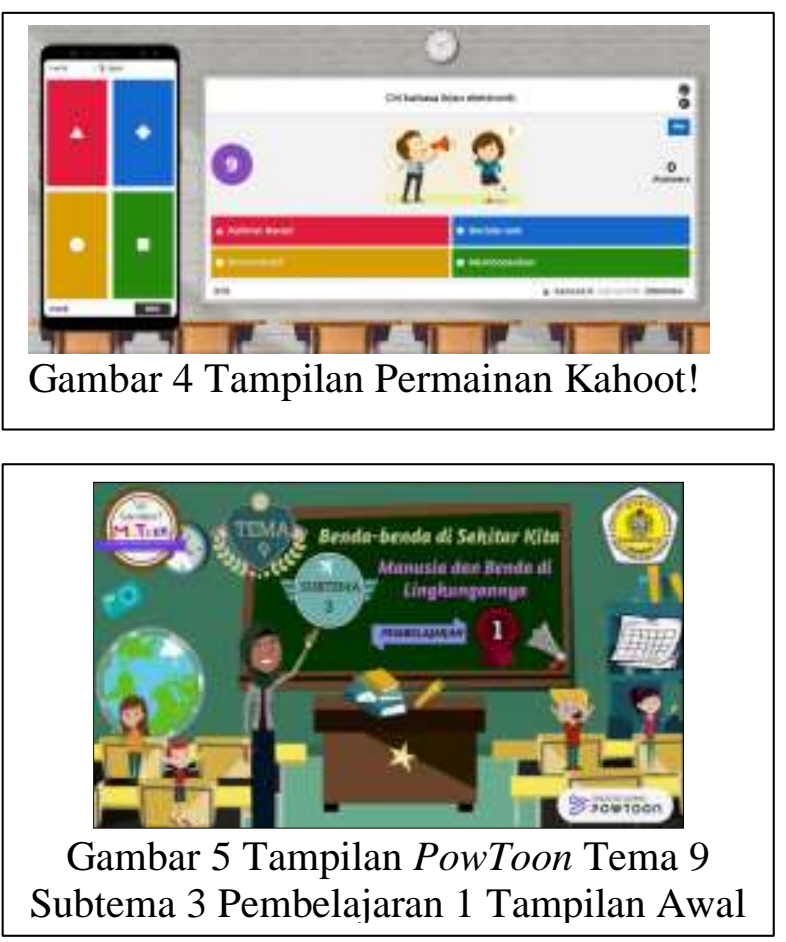

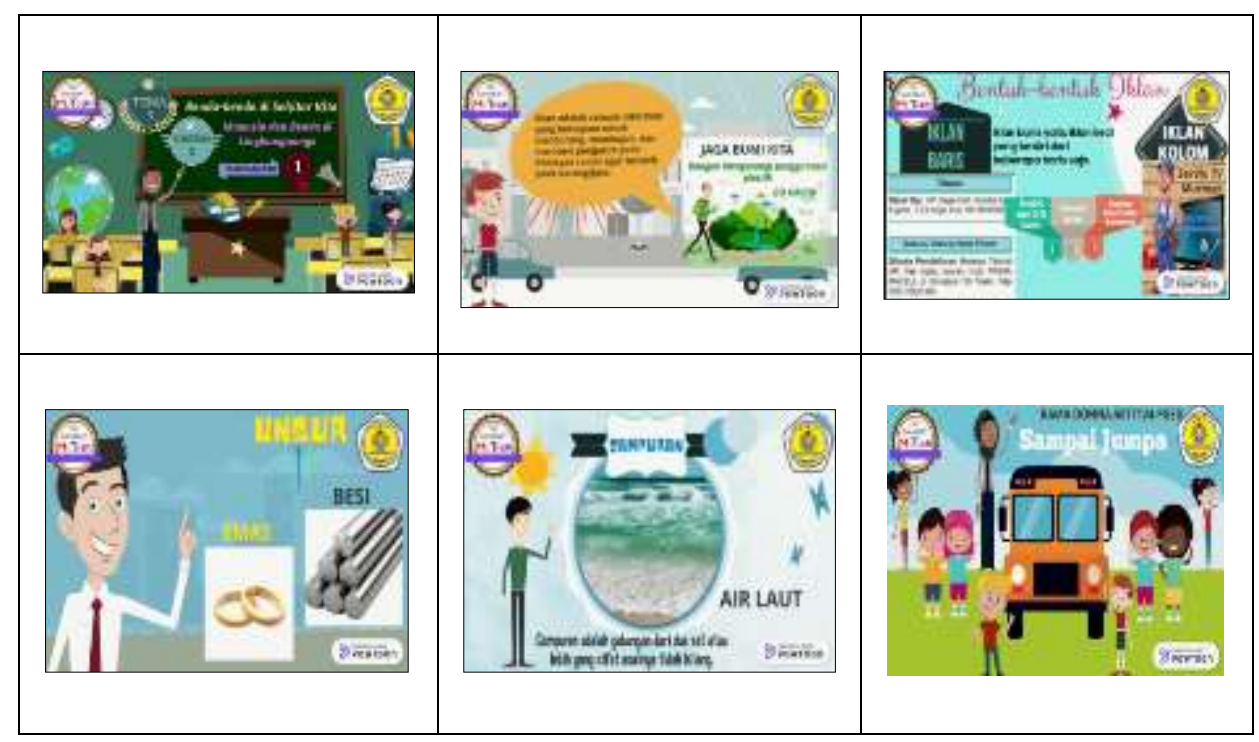

Gambar 6 Tampilan PowToon Tema 9 Subtema 3 Pembelajaran 1 
Validasi ahli materi menggunakan instrumen berupa uji angket tertutup. Angket terdiri dari 11 pernyataan dengan skor tertinggi 4 dan terendah 1 serta dibuat dalam bentuk ceklist.

Tabel 9 Hasil Penilaian dari Ahli Materi

\begin{tabular}{|c|c|c|c|}
\hline Aspek Penilaian & $\begin{array}{c}\text { Banyak } \\
\text { Butir }\end{array}$ & $\begin{array}{l}\text { Angka } \\
\text { Aiken's } V\end{array}$ & $\begin{array}{c}\text { Kriteria } \\
\text { Koefisien } \\
\text { Aiken's V }\end{array}$ \\
\hline Kelayakan isi & 4 & 0,925 & Tinggi \\
\hline Kurikulum & 2 & 1 & Tinggi \\
\hline Isi Materi & 2 & 0,85 & Tinggi \\
\hline Interaksi & 1 & 1 & Tinggi \\
\hline $\begin{array}{l}\text { Mendorong Keingintahuan } \\
\text { dan Keaktifan }\end{array}$ & 2 & 0,85 & Tinggi \\
\hline V rata-rata & \multicolumn{2}{|c|}{0,925} & Tinggi \\
\hline
\end{tabular}

Berdasarkan tabel 9 di atas diperoleh $\mathrm{V}$ rata-rata 0,925 yang masuk klasifikasi tinggi. Sehingga multimedia interaktif berbasis PowToon telah valid dan layak digunakan dalam pembelajaran dari segi materi.

Validasi ahli bahasa menggunakan instrumen berupa uji angket tertutup. Angket terdiri dari 7 pernyataan dengan skor tertinggi 4 dan terendah 1 serta dibuat dalam bentuk ceklist. Aspek-aspek yang dinilai yaitu kebahasaan yang terdapat pada multimedia.

Tabel 10 Hasil Penilaian dari Ahli Bahasa

\begin{tabular}{cccc}
\hline Aspek Penilaian & $\begin{array}{c}\text { Banyak } \\
\text { Butir }\end{array}$ & $\begin{array}{c}\text { Angka } \\
\text { Aiken's } \boldsymbol{V}\end{array}$ & $\begin{array}{c}\text { Kriteria } \\
\text { Koefisien } \\
\text { Aiken's } \boldsymbol{V}\end{array}$ \\
\hline Bahasa & 7 & 0,74 & Cukup Tinggi \\
\hline V rata-rata & \multicolumn{2}{c}{$\mathbf{0 , 7 4}$} & Cukup Tinggi \\
\hline
\end{tabular}

Berdasarkan tabel $10 \mathrm{di}$ atas diperoleh $\mathrm{V}$ rata-rata 0,74 yang klasifikasi Cukup Tinggi. Sehingga multimedia interaktif berbasis PowToon telah valid dan layak digunakan dalam pembelajaran dari segi bahasa.

Validasi ahli media menggunakan instrumen berupa uji angket tertutup. Angket terdiri dari 7 pernyataan dengan skor tertinggi 4 dan terendah 1 serta dibuat dalam bentuk ceklist. Aspek-aspek yang dinilai yaitu kebahasaan yang terdapat pada multimedia.

Tabel 11 Hasil Penilaian dari Ahli Media

\begin{tabular}{cccc}
\hline Aspek Penilaian & $\begin{array}{c}\text { Banyak } \\
\text { Butir }\end{array}$ & $\begin{array}{c}\text { Angka } \\
\text { Aiken's } \boldsymbol{V}\end{array}$ & $\begin{array}{c}\text { Kriteria } \\
\text { Koefisien } \\
\text { Aiken's } \boldsymbol{V}\end{array}$ \\
\hline $\begin{array}{c}\text { Tampilan secara } \\
\text { menyeluruh }\end{array}$ & 2 & 0,70 & Cukup Tinggi \\
\hline Grafis & 2 & 0,70 & Cukup Tinggi \\
\hline Cakupan isi & 2 & 0,50 & Cukup \\
\hline Pewarnaan & 2 & 0,85 & Tinggi \\
\hline Desain isi multimedia & 2 & 0,70 & Cukup Tinggi \\
\hline
\end{tabular}



Dasar - Rama Donna, Asep Sukenda Egok, Riduan Febriandi

DOI: https://doi.org/10.31004/basicedu.v5i5.1382

\begin{tabular}{crrrr}
\hline Keseimbangan elemen & 2 & & 0,70 & Cukup Tinggi \\
\hline V rata-rata & $\mathbf{0 , 7 0}$ & Cukup Tinggi \\
\hline
\end{tabular}

Berdasarkan tabel 11 di atas diperoleh V rata-rata 0,70 yang masuk klasifikasi Cukup Tinggi. Sehingga multimedia interaktif berbasis PowToon telah valid dan layak digunakan dalam pembelajaran dari segi media.

Tabel 12 Rekapitulasi Penilaian dari Validator

\begin{tabular}{clcccc}
\hline \multirow{2}{*}{ No } & \multirow{2}{*}{ Nama } & \multicolumn{3}{c}{ Perolehan Skor } & \multirow{2}{*}{ Klasifi-kasi } \\
\cline { 2 - 5 } & & Materi & Bahasa & Media & \\
\hline 1 & Tio Gusti Satria, M.Pd. & 0,925 & - & - & Tinggi \\
\hline 2 & Dr. Satinem, M. Pd. & - & 0,74 & - & Cukup Tinggi \\
\hline 3 & Dr. Dodik Mulyono, M. Pd. & - & - & 0,70 & Cukup Tinggi \\
\hline & Jumlah & 0,925 & 0,74 & 0,70 & \\
\cline { 2 - 5 } & Rata-rata & & $\mathbf{0 , 7 8}$ & & Cukup Tinggi \\
\hline
\end{tabular}

Hasil evaluasi dari ahli materi, ahli bahasa, dan ahli media terhadap multimedia interaktif berbasis PowToon memperoleh rata-rata skor 0,78 yang masuk klasifikasi Cukup Tinggi. Sehingga dapat disimpulkan bahwa multimedia interaktif berbasis PowToon pada pembelajaran tematik valid dan layak untuk digunakan dalam pembelajaran.

Uji coba kelompok kecil dilakukan untuk melihat tingkat kepraktisan multimedia. Uji kelompok kecil menggunakan instrumen berupa uji angket tertutup yang terdiri dari 12 pernyataan dengan skor tertinggi 1 dan terendah 0 serta dibuat dalam bentuk ceklist dengan jumlah responden 3 orang.

Tabel 13 Hasil Respon Siswa Pada Uji Coba Kelompok Kecil

\begin{tabular}{ccccc}
\hline No & Pernyataan & Responden & Persentase & Klasifikasi \\
\hline 1 & P1 & 3 orang & $100 \%$ & Sangat Praktis \\
\hline 2 & P2 & 3 orang & $100 \%$ & Sangat Praktis \\
\hline 3 & P3 & 3 orang & $100 \%$ & Sangat Praktis \\
\hline 4 & P4 & 3 orang & $100 \%$ & Sangat Praktis \\
\hline 5 & P5 & 3 orang & $100 \%$ & Sangat Praktis \\
\hline 6 & P6 & 3 orang & $100 \%$ & Sangat Praktis \\
\hline 7 & P7 & 3 orang & $100 \%$ & Sangat Praktis \\
\hline 8 & P8 & 3 orang & $100 \%$ & Sangat Praktis \\
\hline 9 & P9 & 3 orang & $100 \%$ & Sangat Praktis \\
\hline 10 & P10 & 3 orang & $100 \%$ & Sangat Praktis \\
\hline 11 & P11 & 3 orang & $100 \%$ & Sangat Praktis \\
\hline 12 & P12 & 3 orang & $100 \%$ & Sangat Praktis \\
\hline & & $\mathbf{1 0 0 \%}$ & Sangat Praktis \\
\hline
\end{tabular}

Berdasarkan tabel 13 diketahui bahwa setiap pernyataan memiliki klasifikasi sangat praktis. Hal ini menunjukkan rata-rata dari 12 pernyataan tersebut yaitu 100\%. Sehingga multimedia interaktif berbasis PowToon dinyatakan praktis dan dapat digunakan untuk uji coba lapangan.

Uji coba lapangan dilakukan untuk melihat tingkat kepraktisan multimedia. Uji kelompok kecil menggunakan instrumen berupa uji angket tertutup yang terdiri dari 12 pernyataan dengan skor tertinggi 1 dan terendah 0 serta dibuat dalam bentuk ceklist dengan jumlah responden 15 orang. 

Dasar - Rama Donna, Asep Sukenda Egok, Riduan Febriandi

DOI: https://doi.org/10.31004/basicedu.v5i5.1382

Tabel 14 Hasil Respon Siswa Pada Uji Coba Lapangan

\begin{tabular}{ccccc}
\hline No & Pernyataan & Responden & Persentase & Klasifikasi \\
\hline 1 & P1 & 15 orang & $100 \%$ & Sangat Praktis \\
\hline 2 & P2 & 15 orang & $93 \%$ & Sangat Praktis \\
\hline 3 & P3 & 15 orang & $100 \%$ & Sangat Praktis \\
\hline 4 & P4 & 15 orang & $100 \%$ & Sangat Praktis \\
\hline No & Pernyataan & Responden & Persentase & Klasifikasi \\
\hline 5 & P5 & 15 orang & $100 \%$ & Sangat Praktis \\
\hline 6 & P6 & 15 orang & $100 \%$ & Sangat Praktis \\
\hline 7 & P7 & 15 orang & $100 \%$ & Sangat Praktis \\
\hline 8 & P8 & 15 orang & $93 \%$ & Sangat Praktis \\
\hline 9 & P9 & 15 orang & $100 \%$ & Sangat Praktis \\
\hline 10 & P10 & 15 orang & $100 \%$ & Sangat Praktis \\
\hline 11 & P11 & 15 orang & $100 \%$ & Sangat Praktis \\
\hline 12 & P12 & 15 orang & $100 \%$ & Sangat Praktis \\
\hline & & $\mathbf{9 8 \%}$ & Sangat Praktis \\
\hline
\end{tabular}

Berdasarkan tabel 14 diketahui bahwa tingkat kepraktisan menunjukkan persentase $98 \%$ dengan klasifikasi sangat praktis. Sehingga multimedia interaktif berbasis PowToon dinyatakan praktis dan dapat digunakan dalam pembelajaran Tematik.

Selain dari angket respon siswa untuk mengetahui tingkat kepraktisan guru juga menjadi respondennya yaitu dengan memberikan instrument berupa uji angket tertutup berisi beberapa pernyataan menggunakan checklist $(\sqrt{ })$ yang dihitung dengan dengan skor yang digunakan terdiri dari $4,3,2,1$.

Tabel 15 Hasil Uji Kepraktisan Guru

\begin{tabular}{clccc}
\hline No & \multicolumn{1}{c}{ Pernyataan } & $\begin{array}{c}\text { Banyak } \\
\text { Butir }\end{array}$ & Persentase & Klasifikasi \\
\hline 1 & Multimedia mudah digunakan/dioperasikan. & 1 & $100 \%$ & Sangat Praktis \\
\hline 2 & Petunjuk multimedia mudah dipahami. & 1 & $100 \%$ & Sangat Praktis \\
\hline 3 & Memudahkan dalam penyampaian materi. & 1 & $100 \%$ & Sangat Praktis \\
\hline 4 & Pembelajaran efisien tanpa membuangwaktu. & 1 & $100 \%$ & Sangat Praktis \\
\hline 5 & $\begin{array}{l}\text { Penyampaian informasi lebih baik dan } \\
\text { mudah diterima. }\end{array}$ & 1 & $100 \%$ & Sangat Praktis \\
\hline 6 & Materi sesuai KD. & 1 & $100 \%$ & Sangat Praktis \\
\hline 7 & Materi sesuai dengan tujuan pembelajaran. & 1 & $100 \%$ & Sangat Praktis \\
\hline 8 & Penyajian desain menarik. & 1 & $100 \%$ & Sangat Praktis \\
\hline 9 & Membuat siswa termotivasi belajar. & 1 & $100 \%$ & Sangat Praktis \\
\hline 10 & $\begin{array}{l}\text { Tulisan dan penyusunan kalimat jelas } \\
\text { ampilan menarik dan mudah dipahami. }\end{array}$ & 1 & $100 \%$ & Sangat Praktis \\
\hline 11 & $\begin{array}{l}\text { Dapat digunakan sebagai pembelajaran } \\
\text { mandiri. }\end{array}$ & 1 & $100 \%$ & Sangat Praktis \\
\hline
\end{tabular}

Berdasarkan tabel 15 diketahui bahwa rata-rata setiap pernyataan memiliki klasifikasi sangat praktis. Hal ini menunjukkan rata-rata dari 11 pernyataan tersebut yaitu 100\%. Sehingga multimedia interaktif berbasis PowToon dinyatakan praktis dari segi respon guru dan dapat digunakan dalam pembelajaran tematik.

Tabel 16 Rekapitulasi dari Penilaian Respon Guru dan Siswa

\begin{tabular}{cccccc}
\hline No & Penilai & Butir Pernyataan & Skor & Persentase & Klasifikasi \\
\hline 1 & Guru & 11 & 11 & $100 \%$ & Sangat Praktis \\
\hline
\end{tabular}


3811 Pengembangan Multimedia Interaktif Berbasis Powtoon pada Pembelajaran Tematik di Sekolah Dasar - Rama Donna, Asep Sukenda Egok, Riduan Febriandi

DOI: https://doi.org/10.31004/basicedu.v5i5.1382

\begin{tabular}{cccccc}
\hline 2 & 3 Siswa & 36 & 36 & $100 \%$ & Sangat Praktis \\
\hline 3 & 15 Siswa & 180 & 178 & $98 \%$ & Sangat Praktis \\
\hline Total & 227 & 225 & $\mathbf{9 9 \%}$ & Sangat Praktis \\
\hline
\end{tabular}

Penilaian kepraktisan melalui angket respon guru dan juga siswa diketahui mendapatkan tingkat kepraktisan sebesar 99\% dengan klasifikasi sangat praktis. Sehingga multimedia interaktif berbasis PowToon dinyatakan praktis dan dapat digunakan dalam pembelajaran tematik.

Penilaian efek potensial dilakukan dengan melihat hasil tes pretest dan posttest yang akan dihitung nilai akhirnya dan rata-rata setiap tes. Dari hasil rata-rata pretest dan posttest akan dihitung hasil tes dengan rumus $\mathrm{N}$-gain (g). Setelah itu, hasil N-gain akan diklasifikasikan untuk mengetahui tingkat efek potensial dari data hasil pretest dan posttest, sehingga dapat diketahui efek potensial dari multimedia interaktif berbasis PowToon.

Tabel 17 Rekapitulasi Nilai Pretest dan Posttest

\begin{tabular}{|c|c|c|c|}
\hline No & Subjek & Jumlah Nilai Pretest & $\begin{array}{c}\text { Jumlah Nilai } \\
\text { Posttest }\end{array}$ \\
\hline 1 & $\begin{array}{ll}15 \text { Siswa Kelas V } \\
\text { SD Negeri } 20 \\
\text { Rejang Lebong }\end{array}$ & 839,99 & 1366,55 \\
\hline & Rata-rata & 55,99 & 91,10 \\
\hline & $\mathrm{N}$-gain $(\mathrm{g})$ & \multicolumn{2}{|c|}{0,797} \\
\hline & Klasifikasi & \multicolumn{2}{|c|}{ Tinggi } \\
\hline
\end{tabular}

Perhitungan N-gain $(\mathrm{g})$ :

$$
\begin{aligned}
N-\operatorname{gain}(g)= & \frac{\text { Spost-Spre }}{\text { Smaks-Spre }} \\
& =\frac{91,10-55,99}{100-55,99} \\
& =\frac{35,11}{44,01} \\
& =0,797
\end{aligned}
$$

Berdasarkan tabel 17 diketahui bahwa N-gain (g) yang didapat dari rata-rata hasil pretest dan posttest yaitu sebesar 0,797 dengan klasifikasi tinggi. Sehingga multimedia interaktif berbasis PowToon dinyatakan memiliki efek potensial yang tinggi dan dapat digunakan dalam pembelajaran tematik.

Tahap penyebaran (Disseminate).

Tahap Penyebaran (Disseminate) dilakukan secara terbatas hanya kepada kelas V SD Negeri 20 Rejang Lebong. Penyebarannya dilakukan dengan menyebarkan media dengan menerapkan multimedia interaktif berbasis PowToon kepada 15 siswa kelas V. Jadi, masing-masing siswa akan dibagikan satu buah kartu Sahabat MuToon.

Setelah multimedia interaktif berbasis PowToon diuji coba oleh para ahli, kemudian diujicobakan pada uji coba kelompok kecil dan terakhir diujicoba lapangan maka didapatkan hasil bahwa multimedia interaktif berbasis PowToon dinyatakan valid, praktis dan memiliki efek potensial sehingga dapat digunakan dalam pembelajaran Tematik. Hal ini selaras dengan penelitian yang dilakukan oleh (Ponza et al., 2018) bahwa video animasi PowToon yang dikembangkan terbukti valid dan efektif meningkatkan hasil belajar siswa. Selaras dengan itu diungkapkan pula oleh (Awalia et al., 2019) bahwa media pembelajaran animasi PowToon dapat memberikan pemahaman kepada siswa kelas V. Selain itu, diungkapkan juga oleh (Egok \& Hajani, 2018:143) bahwa penggunaan multimedia interaktif dapat memberikan pengalaman yang bermakna bagi siswa, karena dalam penggunaannya dapat mempermudah siswa dalam memahami konsep abstrak pada materi menjadi lebih nyata. 
3812 Pengembangan Multimedia Interaktif Berbasis Powtoon pada Pembelajaran Tematik di Sekolah Dasar-Rama Donna, Asep Sukenda Egok, Riduan Febriandi

DOI: https://doi.org/10.31004/basicedu.v5i5.1382

\section{KESIMPULAN}

Berdasarkan penelitian yang telah dilakukan dan pembahasan di atas dapat disimpulkan bahwa Multimedia Interaktif Berbasis PowToon Pada Pembelajaran Tematik Kelas V dinyatakan valid oleh ahli materi, ahli bahasa dan ahli media. Sehingga layak digunakan dalam pembelajaran Tematik. Multimedia Interaktif Berbasis PowToon dinyatakan sangat praktis setelah diujicobakan kepada peserta didik dan guru. Praktikalitas telah diujicobakan pada uji coba kelompok kecil (small group) dan uji lapangan (field testing). Multimedia Interaktif Berbasis PowToon dinyatakan memiliki efek potensial yang tinggi berdasarkan hasil pretest dan posttest, sehingga Multimedia Interaktif Berbasis PowToon layak digunakan dalam pembelajaran Tematik kelas V.

\section{DAFTAR PUSTAKA}

Anjarsari, E., Farisdianto, D. D., \& Asadullah, A. W. (2020). Pengembangan Media Audiovisual Powtoon Pada Pembelajaran Matematika Untuk Siswa Sekolah Dasar. Jurnal Matematika Dan Pendidikan Matematika, 5(2), 40-50.

Arsyad, A. (2019). Media Pembelajaran Edisi Revisi Cetakan Ke 21. Depok: Rajagrafindo Persada.

Awalia, I., Pamungkas, A. S., \& Alamsyah, T. P. (2019). Pengembangan Media Pembelajaran Animasi Powtoon Pada Mata Pelajaran Matematika Di Kelas IV SD. Kreano, Jurnal Matematika Kreatif-Inovatif, 10(1), 49-56. Https://Doi.Org/10.15294/Kreano.V10i1.18534

Egok, A. S., \& Hajani, T. J. (2018). Pengembangan Multimedia Interaktif Pada Pembelajaran IPA Bagi Siswa Sekolah Dasar Kota Lubuklinggau. Journal Of Elementary School (JOES), 1(2), 141-157. Https://Doi.Org/10.31539/Joes.V1i2.446

Febriandi, R. (2020). Efektivitas Multimedia Interaktif Terhadap Pembelajaran Matematika Siswa Kelas V SD Negeri 58 Lubuklinggau. Journal Of Elementary School (JOES), 3, 120-128. Https://Doi.Org/Https://Doi.Org/10.31539/Joes.V3i2.1897

Febriandi, R., Susanta, A., \& Wasidi. (2019). Validitas Lks Matematika Dengan Pendekatan Saintifik Berbasis Outdoor Pada Materi Bangun Datar. Jurnal Pembelajaran Dan Pengajaran Pendidikan Dasar, 2(2), 148-158. Https://Doi.Org/10.33369/Dikdas.V2i2.10612

Hamzah, A. (2019). Metode Penelitian \& Pengembangan (Research And Development) Uji Produk Kuantitatif Dan Kualitatif Proses Dan Hasil Dilengkapi Contoh Proposal Pengembangan Desain Uji Kualitatif Dan Kuantitatif. Malang: Literasi Nusantara.

Hidayat, A., \& Irawan, I. (2017). Pengembangan Lks Berbasis Rme Dengan Pendekatan Problem Solving Untuk Memfasilitasi Kemampuan Pemecahan Masalah Matematis Siswa. Jurnal Cendekia: Jurnal Pendidikan Matematika, 1(2), 51-63. Https://Doi.Org/10.31004/Cendekia.V1i2.20

Istiqlal, M. (2017). Pengembangan Multimedia Interaktif Dalam Pembelajaran Matematika. Jipmat, 2(1). Https://Doi.Org/10.26877/Jipmat.V2i1.1480

Lestari, F., Egok, A. S., \& Febriandi, R. (2021). Pengembangan Bahan Ajar Matematika Berbasis Problem Based Learning Pada Siswa Sekolah Dasar. Jurnal Basicedu, 5(110), 395-405.

Mahmud. (2011). Metode Penelitian Pendidikan. Bandung: Pustaka Setia.

Musofa, N., \& Janattaka, N. (2019). Pemanfaatan Media Powtoon Pada Materi Komik Di Sekolah Dasar. Inventa, 3(2), 147-157. Https://Doi.Org/10.36456/Inventa.3.2.A2013

Navirida, E. (2017). Pengembangan Bahan Ajar Matematika Dengan Pendekatan Kontekstual Materi Mengubah Pecahan Ke Bentuk Persen Dan Desimal Serta Sebaliknya Untuk Siswa Kelas V SD. 01(01).

Ponza, P. J. R., Jampel, I. N., \& Sudarma, I. K. (2018). Pengembangan Media Video Animasi Pada Pembelajaran Siswa Kelas IV Di Sekolah Dasar. Jurnal Edutech Undiksha, 6(1), 9-19. 
3813 Pengembangan Multimedia Interaktif Berbasis Powtoon pada Pembelajaran Tematik di Sekolah Dasar - Rama Donna, Asep Sukenda Egok, Riduan Febriandi

DOI: https://doi.org/10.31004/basicedu.v5i5.1382

Siregar, L. R., Harlin, \& Syofii, I. (2017). Pengembangan Media Pembelajaran Modul Elektronik Mata Kuliah Diagnosis Kendaraan Di Program Studi Pendidikan Teknik Mesin Universitas Sriwajaya. Jurnal Pendidikan Teknik Mesin, 4(1), 45.

Sugiyono. (2016). Metode Penelitian Kuantitatif, Kualitatif, Dan R\&D. Bandung: Alfabeta.

Sugiyono. (2017). Metode Penelitian Kuantitatif, Kualitatif, Dan R\&D. Bandung: Alfabeta.

Suryani, N., Setiawan, A., \& Putria, A. (2018). Media Pembelajaran Inovatif Dan Pengembangannya. Bandung: Rosda.

Trianto. (2010). Model Pmbelajaran Terpadu Konsep Strategi Dan Implikasinya Dalam Kurikulum Tingkat Satuan Pendidikan (KTSP). Jakarta: Bumi Aksara.

Undang-Undang Nomor 20 Tahun 2003 Tentang Sistem Pendidikan Nasional. (N.D.). 